\title{
ФІЗИКА. МАТЕМАТИКА
}

УДК 004.43:53

DOI: 10.37026/2520-6427-2020-104-4-79-83
Галина ВОЙТКІВ,

кандидат педагогічних наук,

доиент кафедри фізики і методики викладання

Прикарпатського наиіонального університету

імені Василя Стефаника, м. Івано-Франківськ

\section{ОРГАНІЗАЦІ ЕЛЕКТРОННОГО НАВЧАННЯ ФІЗИКИ В ОСВІТНЬОМУ ПРОЦЕСІ ЗАКЛАДУ ЗАГАЛЬНОЇ СЕРЕДНЬОЇ ОСВІТИ}

У статті розглядається організація електронного навчання фізики в освітньому прочесі закладу загальної середньої освіти, зокрема окреслено його особливості - від постановки иүілей до рефлексї. Обгрунтовано засоби мотивачії учнів до електронного навчання, переваги формуючого оцінювання. Представлено рекомендації щуодо вибору видів діяльності, їх відповідності змісту навчального матеріалу та навчальним завданням. Визначено основні складові методичної системи навчання фізики та способи їх реалізації в електронному навчанні.

Ключові слова: фізика, електронне навчання, навчання впродовж життя, дистаниійне навчання.

The article considers the organization of e-learning of physics in the educational process of general secondary education, in particular, outlines its features - from goal setting to reflection. The peculiarities of the organization of the main stages of the educational process in physics from goal setting to reflection are described. The article describes the means of motivating students to e-learning, the benefits of formative assessment, recommendations for choosing activities for their compliance with the content of educational material and educational tasks. The author identifies ways to present material in e-learning: a brief summary or presentation, video experiment or demonstration experiment to enhance understanding of theoretical material, sample exercises and typical tasks, laboratory work to be performed, sites for creating projects and links to virtual excursions in physics are possible, which can best present the obligatory elements of the methodical system of teaching physics (theory, educational physical experiment, problem solving, project activity, excursions). Given the specifics of learning on the Internet, the author analyzes ways to motivate students to learn through the development of their internal motivators: understanding the goals of learning, clarity of progress in learning, constructive response, independence in learning and belonging to the team. The article selects online activities that allow you to achieve the required components of learning outcomes according to B. Bloom. In the article the author notes the need for formative assessment in the learning process and the need for final assessment to establish the level of results achieved.

Key words: physics, e-learning, lifelong learning, distance learning.

Постановка проблеми. Використання онлайнтехнологій у різних сферах стало неодмінною частиною нашого повсякденного життя та діяльності: 3 допомогою цифрових технологій ми спілкуємося, встановлюємо контакти, вирішуємо безліч побутових справ, зрештою - працюємо. Тобто, цифрові технології оточують нас повсюди. Тому для життя в сучасному суспільстві недостатньо лише дисциплінарних знань. Майбутні випускники закладів освіти також повинні знати, як користуватися технологіями для ефективного спілкування та співпраці, створення власних проєктів та майбутньої успішної професійної діяльності.

Крім того, зважаючи на останні події у світі, пов'язані з пандемією COVID-19, яка спричинила до закриття шкіл та інших закладів освіти, сьогодні надзвичайно актуальним у шкільній освіті $є$ питання реалізації ефективного електронного навчання 3 метою здобуття навичок безперервного навчання в сучасному швидкозмінюваному світі.

Аналіз наукових досліджень та публікацій доводить, що проблема електронного навчання фізики $\epsilon$ досить актуальною та досліджується вченими в таких напрямах: загальні теоретико-методологічні основи електронного навчання в контексті розвитку освіти (Н. Морзе, М. Барна, В. Биков, Ю. Жук, О. Спірін, О. Пінчук та ін.); питання дистанційного навчання фізики (В. Бузько, С. Величко, О. Трифонова); використання інформаційно-комунікаційних технологій на уроках фізики (Н. Ментова, О. Пінчук, В. Биков, М. Жалдак, М. Шут, В. Сиротюк та ін.).

Зважаючи на дослідження означених вище вчених, зауважимо, що:

- дистанційне навчання фізики вирішує питання нетривалих відлучень учнів від освітнього процесу внаслідок хвороби; дистанційні курси 
3 даного предмета являють собою набір навчальних матеріалів, з якими має ознайомитися учень;

- шкільні дистанційні курси фізики створюються вчителями-практиками не так часто, адже потребують чимало часу на розробку, а основним видом діяльності все ж залишається навчання в класі;

- на практиці вчителі фізики переважно використовують інформаційно-комунікаційні технології 3 метою унаочнення навчального матеріалу, візуалізації дослідів, які неможливо відтворити в реальних умовах для виконання онлайн-лабораторних робіт, рідше - з метою тестування;

- використання технології змішаного навчання у закладах загальної середньої освіти практикують лише в процесі вивчення окремих тем; більшого поширення вона набула в закладах вищої освіти, де в студентів уже сформовані навички самостійного навчання.

Таким чином, незважаючи на модернізацію способів подачі навчального матеріалу з фізики завдяки електронним засобам, сутність освітнього процесу залишається традиційним: учитель, як і раніше, керує процесом навчання, яке зазвичай відбувається в класі, а до електронного навчання вдається лише за повної відсутності можливості очного навчання.

Зважаючи на викладене вище, мета нашої статті дослідити можливості електронного навчання фізики для його реалізації як цілісного освітнього процесу.

Виклад основного матеріалу. У Національній стратегії розвитку освіти в Україні на період до 2021 року наголошується, що стратегічними напрямами модернізації системи освіти $є$ розвиток інформаційно-ресурсного забезпечення освіти та науки. Відповідно в інших документах, як-от Концепції Нової української школи, проєкті Державного стандарту базової та повної загальної середньої освіти, а також у Навчальній програмі з фізики, зазначається про здатність «ставити цілі та досягати їх, будувати власну траєкторію розвитку, планувати, організовувати, впроваджувати, аналізувати та коригувати власну освітню діяльність, ціннісне ставлення до освіти» [1; 5]; «формування інформаційно-комунікативної компетентності, що забезпечує впевнене, критичне та відповідальне використання цифрових технологій для розвитку і спілкування, здатність безпечно та етично використовувати інформаційно-комунікаційні засоби у навчанні та інших життєвих ситуаціях» [6].

Незважаючи на те, що Україна підтримує інформатизацію в усіх галузях, дослідники визначають і негативні сторони впровадження електронного навчання в освітній процес, зокрема:

- значне навантаження на вчителя у зв'язку з тривалою підготовкою до уроків у класі та підготовкою матеріалів для електронного навчання, що пов'язана 3 використанням комп'ютерних засобів навчання i відповідних програм;

- перевантаженість уроку різноманітними демонстраціями, перетворення його у зорово-звукову композицію при неправильному визначенні дидактичної ролі електронного навчання, його місця в освітньому процесі;

- недостатня методична підготовка вчителя щодо використання електронних засобів навчання на конкретному уроці;

- зниження міжособистістного спілкування при перевантаженні уроку електронними засобами;

- заміна «живого» фізичного експерименту цифровим.
Таким чином, визначення факторів мінімізації негативних сторін електронного навчання загалом та розробка способів оптимізації електронного навчання фізики зокрема $є$ в сучасних умовах надважливим завданням.

Цифрова епоха швидко підпорядковує наше життя своїм правилам. Сьогодні ми вже маємо покоління «дітей-гаджетів», які проводять і надалі проводитимуть значну кількість свого часу в мережі Інтернет. Педагоги повинні сприймати це не лише як негативний момент, а й як додаткову можливість наповнення мережі потрібним контентом, залучаючи таким чином дітей до роботи над ним.

Проведене нами навесні 2020 року анкетування учнів (окремі школи Івано-Франківської області) та вчителів (на курсах підвищення кваліфікації), які в умовах карантину працювали дистанційно, дало можливість зробити певні висновки. Так, було з'ясовано, що: в учнів несформовані навички самостійного навчання; школярі, які виконували завдання дистанційно, постійно потребували зворотного зв'язку з учителем; велика кількість дітей узагалі ігнорувала електронне навчання, ставилася до нього несерйозно. Означені проблеми можна вирішити, якщо електронне навчання буде не доповненням, а повноцінною складовою освітнього процесу, коли діти набуватимуть навичок роботи з електронними курсами та ставитимуться до цієї роботи відповідальніше.

Тому основне завданням, яке стоїть сьогодні перед спільнотою вчителів-практиків, - створити нові або вдосконалити вже наявні онлайн-курси, які б супроводжували очне навчання, були його вагомим доповненням або самостійною одиницею освітнього процесу.

Ключовою ідеєю електронного навчання має бути ідея створення такого освітнього навчального середовища, яке б сприяло самовизначенню й самореалізації особистості, організації освітнього процесу як партнерської комунікації, забезпеченню позитивної психологічної атмосфери на уроці [2].

Із методичної точки зору, фізика - це предмет, що передбачає формування цілісної особистості, ключових та предметних компетентностей. Головними складовими методичної системи навчання фізики, що визначені програмою, є: теорія; навчальний фізичний експеримент, який реалізується передусім через досліди; демонстрації та лабораторні роботи; розв'язування задач; проєктна діяльність; шкільні екскурсії.

У зв'язку $з$ цим електронний навчальний курс повинен містити такі матеріали: короткий опорний конспект чи презентацію; відеодослід чи демонстраційний експеримент (для підсилення розуміння теоретичного матеріалу); типові задачі для розв'язування, а також зразки розв'язування задач; лабораторні роботи; рекомендації щодо створення проєктів; посилання на можливі віртуальні екскурсії з фізики (див. рис.).

Оскільки електронне навчання ми розуміємо як цілісний освітній процес, то варто враховувати всі його ключові моменти - починаючи від мотивації, забезпечення активності учасників освітнього процесу та закінчуючи оцінюванням результатів навчання й рефлексією.

Питання мотивування учнів у навчанні й сьогодні не втрачає своєї актуальності. Слушною у зв'язку 3 цим є думка I. Крячка про те, що «робота вчителя 3 мотиваційною сферою учня має бути зосереджена на тому, щоб він (учень) зрозумів і усвідомив заради чого він вчиться і що його спонукає до навчання» [3]. 


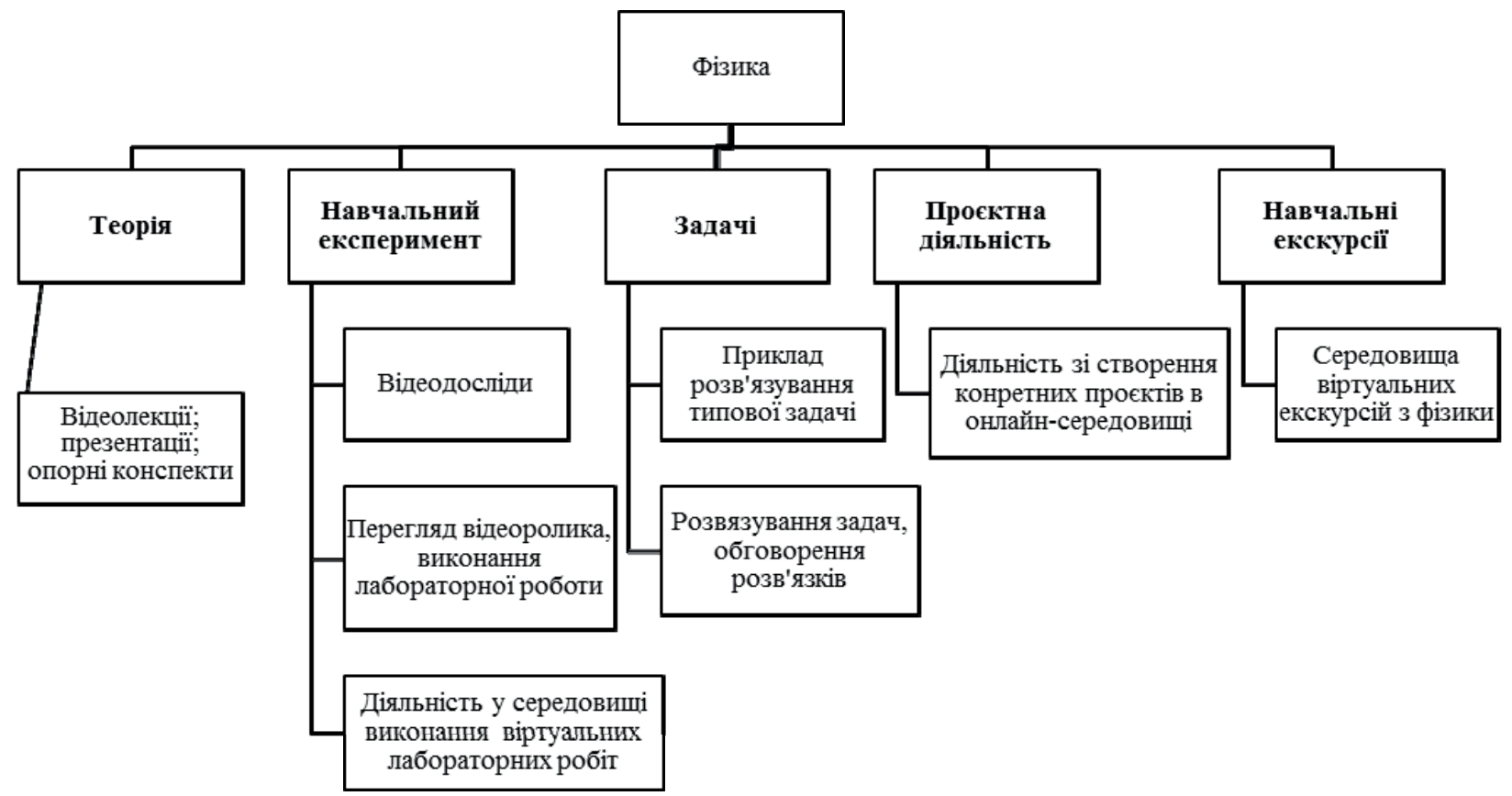

Рис. Компоненти методичної системи вивчення фізики

Із цією метою науковці радять використовувати як зовнішню, так і внутрішню мотивацію. Якщо візуальне представлення курсу, цікаві ресурси, види діяльності сприятимуть зовнішній мотивації, то ефективним навчання буде лише за умови добре розвиненої внутрішньої мотивації.
Внутрішніми мотиваторами для сучасних здобувачів освіти $є$ : розуміння цілей навчання; власний прогрес у навчанні; конструктивний відгук на виконані завдання; самостійність у навчанні; спорідненість (див. табл. 1).

Табличя 1

\section{Шляхи розвитку та підтримки внутрішньої мотивації до навчання}

\begin{tabular}{|c|l|}
\hline Внутрішні мотиватори & \\
\hline Розуміння цілей & - представлена програма курсу; \\
навчання & - наявні приклади результатів навчання; \\
& - присутнє формулювання цілей на кожному етапі навчання; \\
- визначено цілі для кожного виду діяльності
\end{tabular}

Активність учасників освітнього процесу забезпечує досягнення цілей навчання. Активність в електронному навчанні можна забезпечити за допомогою вдало підібраних видів діяльності (обговорення, створення конспекту, розв'язування тестів тощо), що узгоджуватимуться із цілями навчання, а також різноманітних технологій $і$ ичікавих циифрових додатків (створення фізичного кросворда до певної теми, розв'язання анаграм фізичних понять та ін.), які підтримуватимуть інтерес, зроблять навчальну діяльність більш захоплюючою [11].
Добір відповідних видів діяльності, що узгоджуються з особливостями навчання фізики, за таксономією освітніх результатів Б. Блума, повинен узгоджуватися із цілями навчання. У таблиці 2 представлено результати навчання та пов'язані з ними онлайн-заходи, які можуть допомогти здобувачам освіти розвинути знання та навички, що відповідають результатам навчання [8].

Для оцінювання навчальних досягнень з фізики в онлайн-навчанні, ми рекомендуємо використовувати формувальне оцінювання та підсумкове оцінювання [4]. 
Види результатів навчання та пов'язані з ними онлайн-активності

\begin{tabular}{|c|c|}
\hline Тип результатів навчання & Приклади діяльності \\
\hline $\begin{array}{l}\text { Запам'ятовування: } \\
\text { ідентифікація, розпізнавання, перерахування, іменування, отримання }\end{array}$ & $\begin{array}{l}\text { - самотестування онлайн; } \\
\text { - вирішення кросвордів; } \\
\text { - соціальні закладки }\end{array}$ \\
\hline $\begin{array}{l}\text { Розуміння: } \\
\text { узагальнення, пояснення, класифікація, анотування }\end{array}$ & $\begin{array}{l}\text { - дискусійні форуми; } \\
\text { - коментування; } \\
\text { - ведення блогів }\end{array}$ \\
\hline $\begin{array}{l}\text { Застосування: } \\
\text { упровадження, експлуатація, використання, редагування }\end{array}$ & $\begin{array}{l}\text { - моделювання; } \\
\text { - реалізація віртуальних } \\
\text { лабораторій онлайн-проєктів }\end{array}$ \\
\hline $\begin{array}{l}\text { Аналіз: } \\
\text { організація, окреслення, інтеграція, порівняння, перевірка }\end{array}$ & $\begin{array}{l}\text { - анотація відео; } \\
\text { - групові переговори; } \\
\text { - рефлексія }\end{array}$ \\
\hline $\begin{array}{l}\text { Оцінка: } \\
\text { тестування, експериментування, перевірка, оцінювання, модерування, } \\
\text { критикування }\end{array}$ & $\begin{array}{l}\text { - експертна оцінка; } \\
\text { - модерація дискусій; } \\
\text { - інтернет-дебати; } \\
\text { - віртуальні лабораторії; } \\
\text { - інтернет-самотестування }\end{array}$ \\
\hline $\begin{array}{l}\text { Створення: } \\
\text { проєктування, публікація, планування, виготовлення, винахід, } \\
\text { конструювання }\end{array}$ & $\begin{array}{l}\text { - презентації; } \\
\text { - підкасти, вебтрансляції; } \\
\text { - відеозаписи; } \\
\text { - змішування / реміксування; } \\
\text { - цифрова розповідь історій }\end{array}$ \\
\hline
\end{tabular}

Під формувальним оцінюванням розуміємо збір інформації про успішність учнів, яка використовується для поліпшення їхнього навчання та викладання. Таке оцінювання сьогодні є найпотужнішим фактором посилення розуміння навчального матеріалу та усвідомлення отриманих знань [4; 8].

Ефективне формувальне оцінювання в онлайннавчанні забезпечується: програмою; чітким уявленням про результати, яких слід досягти; вмінням учитися на помилках інших людей та правильним використанням конструктивного відгуку на помилки; виконанням тестових завдань; своєчасною присутністю викладача як консультанта й помічника. Разом із тим, підсумкове оцінювання передбачає оцінку предметних і ключових компетентностей. Зокрема, ключові компетентності часто формуються саме через діяльність, підібрану в електронному курсі.

Рефлексія як складова процесу навчання повинна відбуватися не так у межах засвоєного матеріалу, як розуміння основних моментів організації освітнього процесу як такого. Зауважимо, що електронне навчання як освітній процес, зокрема і $з$ фізики, грунтуючись на засадах єдності змістової та процесуальної складових, повинне стати носієм змісту предмета, орієнтувати на вікову динаміку інтересів учнів, набуття ними певного життєвого досвіду, прагнення до успіху. У контексті навчання в класі таке середовище $\epsilon$ зразком зручного інструменту для роботи над темою, коли роль учителя автоматично змінюватиметься із носія інформації на консультанта, асистента, помічника учнів. Діти, вивчаючи тему, матимуть можливість звернутися до будь-якої ії частини вдома, набуваючи при цьому навичок роботи з електронним середовищем, які їм знадобляться у майбутньому.

Варто також зауважити, що серед важливих моментів, на які вчителі повинні звертати увагу при створенні та вдосконаленні електронних курсів з фізики, - вікові можливості дітей та санітарні норми роботи із цифровими пристроями.
Висновки. Сьогодні важливим $є$ перетворення електронного навчання із додатка до освітнього процесу на його невід'ємну складову. Це можливо за умов оптимізації курсів електронного навчання фізики, що являє собою організацію контенту та видів діяльності в електронному навчанні відповідно до наявних видів методичної системи навчання фізики, запланованих результатів навчання та правильного мотивування такого навчання. Правильно впроваджене електронне навчання фізики виконуватиме функції мотивації пізнавальної діяльності учнів, допомагатиме розвитку освітньої самостійності та свідомого навчання, буде сприятливим та безпечним середовищем для формування ключових і предметних компетентностей.

Подальші дослідження у даному напрямі плануємо спрямувати на підбір та методичне обгрунтування цифрових інструментів для забезпечення окремих складових методичної системи навчання фізики, зокрема організації якісного навчального експерименту та формувального оцінювання учнів під час електронного навчання фізики.

\section{СПИСОК ВИКОРИСТАНОЇ ЛІТЕРАТУРИ}

1. Державний стандарт базової і повної загальної освіти. URL: http://ru.osvita.ua/legislation/Ser_ osv/28030/ (дата звернення: 03.09.2020).

2. Корицька Г. Веб-майданчик як навчальне середовище відкритого освітнього простору. Інформаиійні технології $і$ засоби навчання. 2016. Т. 56. № 6 (57). С. 1-9.

3. Крячко I. Методика навчання астрономії в старшій загальноосвітній школі. Київ : ВЦ «Наше небо», 2018. 244 с.

4. Морзе Н. В., Барна О. В., Вембер В. П. Формувальне оцінювання: від теорії до практики. Інформатика та інформаційні технології в навчальних заклаdax. 2013. № 6. C. 45-57. 
5. Нова українська школа. Концептуальні засади реформування середньої школи. URL: https://mon. gov.ua/storage/app/media/zagalna $\% 20$ serednya/novaukrainska-shkola-compressed.pdf (дата звернення: 23.08.2020).

6. Фізика. 7-9 класи. Навчальна програма для загальноосвітніх навчальних закладів. URL: https:// ru.osvita.ua/school/program/program-5-9/56124/

7. Sclater N. Web 2.0, Personal Learning Environments, and the Future of Learning Management Systems (Research Bulletin, Issue 13). Boulder, CO: EDUCAUSE Center for Applied Research. 2008. URL: http://www.educause.edu/ecar (дата звернення: 23.08.2020).

8. Blum B. Handbook on formative and summative evaluation of student learning by Blum. Madaus, 1971.

9. Bonk C. Graham C. Handbook of blended learning: Global perspectives, localdesigns. SanFrancisco, CA: PfeifferPublishing, 2005.
10. Sclater N. Web 2.0, Personal Learning Environments, and the Future of Learning Management Systems (Research Bulletin, Issue 13). URL: http://www.educause.edu/ecar (дата звернення: 23.08.2020).

11. Siemens G. Connectivism: A Learning Theory for the Digital Age. International Journal of Instructional Technology and Distance Learning. 2005. Vol. 2. No. 1. URL: http://www.elearnspace.org/Articles/connectivism.htm (дата звернення: 01.09.2020).

12. Saadatmand M., Kumpulainen K. Emerging Technologies and New Learning Ecologies: Learners' Perceptions of Learning in Open and Networked Environments. Proceedings of the 8th International Conference on Networked Learning / Department of Teacher Education, University of Helsinki ; Edited by: V. Hodgson, C. Jones, M. Laat, D. McConnell, T. Ryberg, P. Sloep. 2012. P. 266-275.

Дата надходження до редакиї: 16.09.2020 p.

Тарас ГАЛАТЮК,

учитель фізики та інформатики

ЗЗСО № 6 м. Рівного, магістр фізики

Юрій ГАЛАТЮК, кандидат педагогічних наук, професор, професор кафедри фізики, астрономії та методики викладання

Рівненського державного гуманітарного університету

\section{ФОРМУВАННЯ МЕТОДОЛОГІЧНОЇ КУЛЬТУРИ УЧНІВ З ФІЗИКИ У ПРОЦЕСІ ТВОРЧОЇ ПІЗНАВАЛЬНОї ДІЯЛЬНОСТІ}

У статті акиентується увага на формуванні креативного і продуктивного компонентів методологічної культури учнів у контексті реалізації Концепиії Нової украӥнської школи. Доведено, щзо повноцінне формування означених компонентів не можливе без залучення учнів до творчої пізнавальної діяльності. Розкриваються теоретичні та практичні механізми організачії творчої навчально-пізнавальної діяльності під час вивчення фізики у контексті формування методологічної культури учнів, засвоєння методологічних знань та компетентностей. Аналізується творча пізнавальна діяльність як предмет проєктування $і$ організачї вчителем навчальної діяльності. Схарактеризовані проиес моделювання та організації творчої пізнавальної діяльності на основі виконання фізичних дослідів та навчального спостереження.
Ключові слова: методологічна культура, педагогічне проєктування, творча пізнавальна діяльність, навчальне спостереження.

The article focuses on the formation of creative and productive components of the methodological culture of students in the context of the implementation of the concept of the New Ukrainian school. The full formation of these components is not possible without involving students in creative cognitive activity. Creative cognitive activity is the subject of design and organization by the teacher.

Theoretical and practical mechanisms of organization of creative educational and cognitive activity during the study of physics in the context of formation of methodological culture of students, assimilation of methodological knowledge and competencies are revealed. 